УДК 618.523.7-082-047.74

DOI 10.11603/24116-4944.2018.1.8792

๑о. М. Каланжова, С. Р. Галич, М. І. Щурко, Д. М. Щурко

Одесъкий національний медичний університет

\title{
ПЛАНУВАННЯ ПОЛОГІВ - СУЧАСНИЙ ПІДХІД В АКУШЕРСТВІ ПРИ ТАЗОВОМУ ПЕРЕДЛЕЖАННІ ПЛОДА
}

Мета дослідження - оцінити ефективність та обґрунтованість індивідуального планування пологів при тазовому передлежанні плода (ТПП).

Матеріали та методи. Вагітні були розподілені на 2 групи: I - основна група (ОГ) (n=36), жінки з запланованими консервативними пологами при ТПП; II - контрольна група (КГ) (n=33), жінки з запланованим кесаревим розтином при ТПП.

Результати дослідження та їх обговорення. Завершення вагітності більшості пацієнток обох груп відбулося запланованим способом розродження: ОГ - 27 (75 \%); КГ - 29 (87,8 \%). Пацієнтки ОГ народжували у колінно-ліктьовій позиції - 11 $(40,7 \%)$ та за допомогою методу Цов'янова - 16 (59,3 \%). А випадки кесаревого розтину - 9 (25 \%) в ОГ - здебільшого I категорії ургентності - 5 (55,5\%). Потреба в ургентному кесаревому розтині в КГ виникала майже в два рази менше - 4 $(12,2 \%)$ та більшість випадків - 3 (75 \%) мали III категорію ургентності. Серед малюків ОГ, яким надавалася ручна допомога під час народження, перинатальні ускладнення траплялися найчастіше: пологова травма - 8 (22,2 \%), асфріксія - 3 (8,3 \%), аспірація - 2 (5,55 \%), гіпоксично-ішемічне ураження головного мозку - 3 (8,3 \%).

Висновок. Зазначене свідчить про відсутність високопрофесійних навичок, що потребує ретельного відпрацювання та вдосконалення пологодопоміжних маніпуляцій лікарів акушерів-гінекологів.

Ключові слова: тазове передлежання плода; консервативні пологи; кесарів розтин; перинатальні наслідки.

ПЛАНИРОВАНИЕ РОДОВ - СОВРЕМЕННЫЙ ПОДХОД В АКУШЕРСТВЕ ПРИ ТАЗОВОМ ПРЕДЛЕЖАНИИ ПЛОДА

Цель исследования - оценить эффрективность и обоснованность индивидуального планирования родов при тазовом предлежании плода (ТПП).

Материалы и методы. Беременные были разделены на 2 группы: I - основная группа (ОГ) (n=36), женщины с запланированными консервативными родами при ТПП; II - контрольная группа (КГ) (n=33), женщины с запланированным кесаревым сечением при ТПП.

Результаты исследования и их обсуждение. Завершение беременности большинства пациенток обеих групп произошло запланированным способом: ОГ - 27 (75 \%); КГ - 29 (87,8 \%). Пациентки ОГ рожали в коленно-локтевой позиции 11 (40,7 \%) и с помощью метода Цовьянова - 16 (59,3 \%). А случаи кесарева сечения - 9 (25 \%) в ОГ - преимущественно I категории ургентности - 5 (55,5\%). Потребность в ургентном кесаревом сечении в КГ возникала почти в два раза меньше - 4 (12,2 \%) и большинство случаев - 3 (75 \%) имели III категорию ургентности. Среди детей ОГ, которым оказывалась ручная помощь при рождении, перинатальные осложнения встречались чаще: родовая травма - 8 (22,2 \%), асфиксия - 3 (8,3\%), аспирация - 2 (5,55 \%), гипоксически-ишемическое поражение головного мозга - 3 (8,3 \%).

Вывод. Представленные данные свидетельствуют об отсутствии высокопрофессиональных навыков, требующих тщательной отработки и совершенствования родовспомогательных манипуляций врачами акушерами-гинекологами.

Ключевые слова: тазовое предлежание плода; консервативные роды; кесарево сечение; перинатальные исходы.

DELIVERY PLANNING: A CONTAMPORARY APPROACH TO BREECH PRESENTATION IN OBSTETRICS

The aim of the study - to evaluate the effectiveness and the validity of individual delivery planning for breech presentations.

Materials and Methods. Pregnant patients were divided into two groups: 1$)$ the main group (MG) $(n=36)$ which included women with planned conservative deliveries for breech presentations; 2$)$ the control group (CG) $(n=33)$ which included women with planned cesarean deliveries for breech presentations.

Results and Discussion. Pregnancy completion in the majority of patients from both groups occurred in the planned way: MG - 27 (75\%), CG - 29 (87.8\%). The MG patients gave birth in the knee-elbow position - $11(40.7 \%)$ and with the help of Tsovianov method - 16 (53.9\%). There were 9 (25\%) cases of cesarean deliveries in the CG which were mainly classified as the 1st urgency category - 5 (55.5\%). The need for urgent cesarean section in the CG occurred in half as many cases $-4(12.2 \%)$ and most cases - $3(75 \%)$ - had the 3rd urgency category. Perinatal complications were more common among the children from the CG who had received manual help at birth: birth trauma - 8 (22.2 \%), asphyxia - 3 (8.3 \%), aspiration - 2 (5.55 \%), hypoxicischemic brain damage $-3(8.3 \%)$.

Conclusions. The presented data indicate the lack of highly professional skills which require thorough execution and improvement of obstetrical manipulations by obstetricians and gynecologists.

Key words: breech position; conservative delivery; cesarean section; perinatal outcomes.

ВстУп. Пологи при тазовому передлежанні плода (ТПП) - питання, що впродовж тривалого часу залишається предметом дискусій та тактичних контраверсій для науковців багатьох країн світу. Так, опубліковані в 2000-х роках результати мультицентрових рандомізованих контрольованих досліджень Term breech Trial, PREMODA кардинально змінили парадигму ведення пологів при доношеній вагітності одним плодом у тазовому передлежанні в бік абдомінального способу розродження. А оновлення національних рекомендацій та клінічних про- 
токолів призвело до ще більшої концентрації акушерівгінекологів на оперативному розродженні і знехтування вивчення можливості покращення та більш широкого впровадження консервативних пологів у пацієнток із ТПП $[1,2]$. Привертає увагу те, що при досить стабільній та невисокій частоті випадків ТПП у популяції (3-5 \%) наслідками вищезазначених клінічних підходів стали: незмінні перинатальні втрати - до 1/4 всіх випадків, збільшення кількості випадків кесаревого розтину у розвинутих країнах - 70-100 \%, збільшення материнської захворюваності та смертності, а також погіршення подальшої репродуктивної функції пацієнток. Такі показники свідчать про наближення сучасної акушерської допомоги до межі оперативного розродження, за якою результати не виправдовують очікування, а ризики ятрогенних ускладнень стають надто високими як для матері, так і для новонародженого [3-7]. Більш пізні дослідження в зазначеному напрямку (Maggie Banks - New Zealand) демонструють можливість зниження ускладнень консервативних пологів при ТПП до відповідних при головному його передлежанні за умов певного відбору пацієнток до таких пологів. Таким чином, наведені дані підтверджують неефективність та необґрунтованість використання єдиного підходу у пологах при ТПП [8, 9]. А сьогодення диктує необхідність подальшого пошуку та оптимізації принципово нових шляхів до ведення пологів при ТПП, що дозволить зробити їх планованими, індивідуальними та максимально безпечними для кожної вагітної.

МЕТА ДОСЛІДЖЕННЯ - оцінити ефективність та обґрунтованість індивідуального планування пологів при ТПП.

МАТЕРІАЛИ ТА МЕТОДИ. Для Досягнення визначеної мети проведено проспективний аналіз 69 випадків попереднього планування способу розродження першо- та повторнонароджуючих пацієнток із доношеною вагітністю одним плодом у тазовому передлежанні (неповне та повне) із припустимою масою плода від 2500 до 4200 г. Жінки групи дослідження або не були кандидатами для проведення операції зовнішнього повороту плода на голівку (мали протипоказання), або письмово відмовлялися від їі проведення. 3 дослідження були виключені пацієнтки із передчасними пологами (<37 тижнів), ножним передлежанням, багатоплідною вагітністю та вродженими вадами розвитку внутрішньоутробної дитини. Всі пологи відбулися на III рівні надання акушерської допомоги в Одеському обласному перинатальному ценрі в 20152017 рр. Вагітні були розподілені на 2 групи: I - основна група (ОГ) (n=36), жінки з ТПП, які планували консервативний спосіб розродження; II - контрольна група (КГ) (n=33), жінки з ТПП, які планували спосіб розродження виключно шляхом операції кесаревого розтину.

Статистичну обробку отриманих результатів проводили за допомогою програмного забезпечення Microsoft Office Excel 2016 із використанням статистичних методів варіаційного, непараметричного аналізу. Статистично значущими вважались значення $p<0,05$.

РЕЗУЛЬТАТИ ДОСЛІДЖЕННЯ ТА ЇХ ОБГОВОРЕНня. Середній вік жінок у групах дослідження становив $(27,1 \pm 1,5)$ року - ОГ та $(28,3 \pm 1,3)$ року - КГ. Клініко-статистичний аналіз стану соматичного та репродуктивного здоров'я пацієнток показав відповідність провідних показників в обох групах.
Так, частота екстрагенітальної патології у пацієнток груп дослідження не розрізнялася 3 боку: дихальної системи ОГ - 1 (2,7 \%), КГ - 1 (3 \%); шлунково-кишкового тракту ОГ - $9(25 \%)$, КГ - $8(24,2 \%)$ та сечовивідної системи ОГ - 6 (16,7\%), КГ - 4 (12,1\%) (р>0,05). При цьому захворювання центральної нервової системи ОГ - 2 (5,5 \%), КГ - 5 (15,1\%) та серцево-судинної системи ОГ - 7 (19,4 \%), КГ - 2 (6,1 \%) за частотою свого визначення в обох групах достовірно розрізнялися $(p<0,05)$. Увагу привертає те, що з боку патології центральної нервової системи в КГ превалювала епілептична хвороба із частими нападами - 3 (60 \%), що сама по собі визначала оперативний спосіб розродження таких вагітних. При цьому з боку захворювань серцево-судинної системи в ОГ більш ніж половину випадків становила варикозна хвороба - 4 (57,1\%), що вимагає планування у таких пацієнток консервативного розродження за відсутністю інших протипоказань. Серед переліку екстрагенітальної патології порушення з боку шлунково-кишкового тракту як в ОГ, так і в КГ мала майже кожна четверта вагітна.

Вивчення характеру менструальної фрункції вказує на: пізнє, у віці 15-16 років, менархе - 23 (63,8 \%) - ОГ, 19 (57,6 \%) - КГ та дисменорею - 18 (50,1 \%) - ОГ, 20 $(60,6 \%)$ - КГ у більшості пацієнток обох груп ( $>>0,05)$.

Аномалії розвитку репродуктивної системи ставали чинником відношення пацієнток одразу до КГ у 7 (21 \%) випадках (дворога матка - 4; перетинка порожнини матки -3).

Визначення особливостей акушерсько-гінекологічного анамнезу показало, що першовагітними в ОГ були 11 $(30,5$ \%) жінок, у КГ - 9 (27,2 \%) пацієнток. Від безпліддя (первинного або вторинного) страждали виключно кандидатки КГ - 6 (18,1\%). щодо штучних абортів, то їх кількість превалювала серед досліджуваних ОГ - 17 $(47,2 \%)$, тоді як у КГ зазначений показник був значно меншим та становив $5(15,1 \%)$ випадків $(p<0,05)$. За допомогою репродуктивних технологій вагітність настала в 1 (2,7 \%) пацієнтки ОГ та 4 (12,1 \%) вагітних КГ. Привертає увагу й те, що кількість першонароджуючих пацієнток в ОГ становила 12 (33,3 \%) випадків, що в два рази менше за відповідний показник у КГ - 22 (66,6 \%). Ускладнень післяпологового періоду у повторнонароджуючих жінок досліджуваних груп не було.

Всі пацієнтки груп дослідження були взяті на облік протягом I триместру гестації та відвідували жіночу консультацію регулярно.

Частота ускладнення перебігу теперішньої вагітності раннім токсикозом - 8 (22,2 \%) - ОГ, 13 (39,3\%) - КГ, анемією вагітних легкого ступеня - 10 (27,7 \%) - ОГ, 7 $(21,2 \%)-$ КГ та прееклампсією помірного ступеня - 6 $(16,6 \%)$ - ОГ, 9 (27,2 \%) - КГ у жінок обох груп не мала достовірної різниці ( $>>0,05)$. Випадки таких ускладнень, як загроза переривання вагітності - 8 (22,2 \%) - ОГ, 26 (78,8 \%) - КГ та внутрішньопечінковий холестаз - 1 (2,7\%) - ОГ, 3 (9 \%) - КГ, мали достовірну різницю за частотою виникнення у зазначених групах $(p<0,05)$. Також перебіг вагітності в жінок КГ у 3 (9,1 \%) випадках ускладнювався низькою плацентацією.

Подальше дослідження було спрямоване на визначення відповідності запланованого способу розродження при ТПП до способу розродження, що відбувся, та наслідків запланованих пологів при ТПП для новонароджених залежно від способу їх народження в обох групах. 
Так, наведені дані демонструють завершення вагітності більшості пацієнток обох групах саме запланованим способом: ОГ - 27 (75 \%); КГ - 29 (87,8 \%) (табл. 1).

Пацієнтки ОГ, у свою чергу, народжували консервативним шляхом як за умов повної недоторканості дитини у колінно-ліктьовій позиції жінки - 11 (40,7 \%), так і за допомогою методу Цов'янова у позиції породіллі дорсально - 16 (59,3 \%). Обрання вільної, колінно-ліктьової, позиції в пологах серед жінок ОГ було можливим лише за умов сприятливого перебігу пологів, таких, як: спонтанна активна пологова діяльність протягом всього пологового акту, поступове просування плода по пологовому каналу на тлі продуктивної пологової діяльності, задовільний стан породіллі та внутрішньоутробної дитини. Водночас ретельний монітор перебігу консервативних пологів при ТПП виявляв пацієнток, чиї пологи потребували активного втручання із використанням методу Цов'янова з причин ускладнення у I або II періодах (слабкість пологової діяльності - 11 (68,8 \%), інтранатальний дистрес плода - 5 (31,2\%)).

щодо кесаревого розтину, яким завершилося 9 (25\%) вагітностей серед пацієнток ОГ, то він був наслідком виключно ускладнених планованих консервативних пологів, що потребували перегляду тактики ведення в бік оперативного розродження. Так, його проведення в ургентному порядку в жінок ОГ було зумовлено: передчасним розривом плодових оболонок при незрілій шийці матки (<5 балів за Бішопом) - 2 (22,2\%), первинною слабкістю пологової діяльності - 1 (11,1 \%), вторинною слабкістю пологової діяльності - 1 (11,1 \%), інтранатальним дистресом плода - 3 (33,3\%), випадінням петель пуповини - 1 (11,1 \%) та передчасним відшаруванням нормально розташованої плаценти - 1 (11,1 \%). При цьому слід зазначити, що більшість випадків кесаревого розтину в ОГ - 5 (55,5 \%) відносилися до I категорії ургентності.

В КГ розродження пацієнток запланованим шляхом відбулося в 29 (87,8 \%) випадках - елективний кесарів розтин. Потреба в ургентному кесаревому розтині I та III категорій ургентності серед 4 (12,2 \%) представниць зазначеної групи була обумовлена: передчасним відшаруванням низько розташованої плаценти (I категорія ургентності) - 1 (25\%) випадок та передчасним розривом плодових оболонок (III категорія ургентності) - 3 (75 \%) випадки.
Особливо показовими в питанні планування пологів при тазовому передлежанні плода є дані стосовно новонароджених у групах дослідження. Так, в обох групах всі діти народилися живими. Середня маса новонароджених у КГ становила (3840 260$)$ г та була достовірно більшою за відповідний показник в ОГ - $(3380 \pm 180)$ г $(p<0,05)$. Середня оцінка малюків за шкалою Апгар після народження в КГ (1-ша хвилина - $(7,8 \pm 1,2)$ бала, 5-та хвилина - $(8,6 \pm 1,0)$ бала) була вищою від такої в ОГ (1-ша хвилина - $(5,6 \pm 1,5)$ бала, 5-та хвилина - $(6,7 \pm 0,6)$ бала). А проведення порівняльного аналізу показників стану новонароджених у групах дослідження в ранньому неонатальному періоді показало достовірну різницю (табл. 2).

Стосовно пологових травм плода з'ясовано, що в ОГ вони мали місце у половини новонароджених - 8 (22,2 \%), саме яким у пологах надавалася допомога за Цов'яновим, та полягали у випадках: саден і синців - 7 (87,5 \%) та переломі ключиці - 1 (12,5\%). Пологовий травматизм у КГ траплявся рідше виключно у вигляді синців та був пов'язаний із утрудненою екстракцією крупного плода під час кесаревого розтину - $2(6,1 \%)(p<0,05)$.

Відносно ассріксії під час народження слід наголосити на більш виразному ступені її важкості в ОГ - 3 (8,3\%): середня - $2(66,7 \%)$ та тяжка - 1 (33,3 \%). Серед новонароджених КГ зазначене ускладнення мало місце лише в 1 (3,03 \%) випадку, клінічно проявляло себе легким ступенем та було пов'язане із передчасним відшаруванням нормально розташованої плаценти.

Таке ускладнення, як аспірація навколоплодовою рідиною, демонстрували новонароджені ОГ - 2 (5,55 \%). Зазначене ускладнення виникало на тлі асфріксії в пологах та проявлялося в подальшому синдромом дихальних розладів - 2 (5,55 \%). У КГ зазначене ускладнення місця не мало в жодному випадку.

Гіпоксичні крововиливи у шлуночки мозку, що не зустрічалися в КГ та мали місце серед малюків ОГ - 1 (2,8 \%), у свою чергу, можуть свідчити про тривалу гіпоксію та небездоганне виконання лікарем пологодопоміжних маніпуляцій під час пологів при ТПп.

Такі несприятливі показники перинатальної захворюваності, як гіпоксично-ішемічне ураження головного мозку, можуть бути розцінені наслідком інтранатальної

Таблиця 1. Способи розродження, якими завершилися пологи в групах дослідження

\begin{tabular}{|l|c|c||}
\hline \multicolumn{1}{|c|}{ Спосіб розродження } & ОГ (n=36) & КГ $(\mathrm{n}=33)$ \\
\hline Вагінальні пологи & $27(75 \%)$ & - \\
\hline Кесарів розтин (елективний) & - & $29(87,8 \%)$ \\
\hline Кесарів розтин (ургентний) & $9(25 \%)$ * & $4(12,2 \%)$ \\
\hline
\end{tabular}

Примітка. * - p<0,05 порівняно з КГ.

Таблиця 2. Перинатальні наслідки планованих пологів при ТПп

\begin{tabular}{|l|c|c||}
\hline \multicolumn{1}{|c|}{ Показник } & ОГ $(\mathrm{n}=36)$ & $\mathrm{K} \Gamma(\mathrm{n}=33)$ \\
\hline Пологові травми & $8(22,2 \%)^{*}$ & $1(3,03 \%)$ \\
\hline Ассріксія під час народження & $3(8,3 \%)$ & $0(0 \%)$ \\
\hline Аспірація & $2(5,55 \%)$ & $0(0 \%)$ \\
\hline Гіпоксичні крововиливи у шлуночки мозку & $1(2,8 \%)$ & $1(3,03 \%)$ \\
\hline Гіпоксичні та ішемічні ураження головного мозку & $3(8,3 \%)$ & $0(0 \%)$ \\
\hline Необхідність інтенсивного лікування & $4(11,1 \%)^{\star}$ & \\
\hline
\end{tabular}

Примітка. * - p<0,05 порівняно з КГ. 
гіпоксії внутрішньоутробної дитини різного ступеня важкості. При цьому новонароджені ОГ демонстрували більш важкий перебіг ускладнення: середні та важку фрорми - 3 (8,3 \%). А серед малюків КГ зазначене ускладнення мало виключно легкий ступінь перебігу в 1 (3,03 \%) випадку.

Потреба в інтенсивному лікуванні виникала лише серед малюків ОГ, яким надавалася ручна лікарська допомога під час народження, та становила 4 (11,1 \%) випадки.

ВИСновкИ. 1. Представлені дані свідчать, що у плануванні пологів при тазовому передлежанні плода одним із провідних чинників виступає анамнез вагітної жінки. Такі дані, як: першонароджуюча, безпліддя, вроджені аномалії статевої системи, попередні оперативні втручання на матці та використання допоміжних репродуктивних технологій у настанні вагітності завідомо визначають оперативний спосіб розродження таких пацієнток. Тоді як наявність абортів та пологів в анамнезі є підґрунтям для впевненого обрання вагітними спроби здійснення консервативних пологів.

2. Попереднє планування пологів при тазовому передлежанні плода дає змогу жінці народити найкращим для неї способом, зменшуючи необґрунтовані материнські та перинатальні ризики під час та після пологів. Такий підхід збільшує ймовірність успішності консервативних пологів та зменшує кількість ургентних кесаревих розтинів із притаманним їм більш високим ризиком ускладнень.

3. Перинатальні ускладнення серед малюків ОГ, яким надавалася ручна допомога під час консервативного народження у тазовому передлежанні, свідчать про відсутність стійких вмінь та високопрофресійних навичок сучасних лікарів акушерів-гінекологів. Зазначене потребує відпрацювання та вдосконалення пологодопоміжних маніпуляцій, що дозволить надавати високоефективну та кваліфріковану допомогу у відповідних ситуаціях.

ПЕРСПЕКТИВИ ПОДАЛЬШИХ ДОСЛІДЖЕНЬ У зазначеному напрямку дозволять жінкам із тазовим передлежанням плода отримувати індивідуальний диференційований підхід у питанні планування таких пологів із обранням найкращого способу розродження у кожному окремому випадку, що, у свою чергу, сприятливо вплине на зниження материнських та перинатальних ризиків.

\section{СПИСОК ЛІТЕРАТУРИ}

1. Турсунова Г. А. Влияние новых технологий на исходы родов и состояние здоровья новорожденных, родившихся в тазовом предлежании / Г. А. Турсунова, 3. М. Ахтамова, Х. С. Некбаев // Вестник неотложной и восстановительной медицины. - 2012. - Т. 12, № 1. - С. 34-37.

2. Клінічний протокол з акушерської допомоги «Кесарів розтин» : наказ Міністерства охорони здоров'я України від 27.12.2011 р. № 977 // Репродуктивная эндокринология. 2012. - № 2 (4). - C. 18-33.

3. Burgos J. Management of breech presentation at term: a retrospective cohort study of 10 years of experience / J. Burgos, L. Rodríguez, P. Cobos // Journal of Perinatology. 2015. - Vol. 35, No. 10. - P. 803-808.

4. Влияние течения беременности и родов на состояние здоровья новорожденного ребенка / Е. В. Подсвирова, Т. А. Романова, М. М. Гурова [и др.] // Научные ведомости. - 2014. - T. 24, № 185. - Р. 81-84.

5. Тазовое предлежание: перинатальные аспекты / Ю. В. Давыдова, И. В. Чибисова, Т. Ю. Бабич, Л. И. Падалко // Жіночий лікар. - 2013. - № 4. - С. 27-30.

\section{REFERENCES}

1. Tursunova, G.A., Akhtamova, Z.M., \& Nekbayev, Kh.S. (2012). Vliyaniye novykh tekhnologiy na iskhody rodov i sostoyaniye zdorovya novorozhdennykh, rodivshikhsya $v$ tazovom predlezhanii [The influence of new technologies on outcomes of childbirth and the state of health of newborns born in breech presentation]. Vestnik neotlozhnoy $i$ vosstanovitelnoy meditsiny - Bulletin of Urgent and Rehabilitation Medicine, 12, 1, 34-37 [in Russian].

2. (2012). Klinichnyi protokol z akusherskoi dopomohy "Kesariv roztyn": Nakaz Ministerstva okhorony zdorovia Ukrainy vid 27.12.2011 r. № 977 [Clinical protocol on obstetric care "Caesarean section": Order of the Ministry of Health of Ukraine dated December 27, 2011 No. 977]. Reproduktivnaya endokrinologiya - Reproductive Endocrinology, 2 (4), 18-33 [in Ukrainian].

3. Burgos, J., Rodríguez, L., \& Cobos, P. (2015). Management of breech presentation at term: a retrospective cohort

6. Common determinants of breech presentation at birth in singletons: a population-based study / H. Cammu, N. Dony, G. Martens, R. Colman // European Journal of Obstetrics \& Gynecology and Reproductive. - 2014. Vol. 177. - P. 106-109.

7. Delivery of breech presentation at term gestation in Canada, 2003-2011 / J. Lyons, T. Pressey, S. Bartholomew [et al.] // Obstetrics \& Gynecology. - 2015. - Vol. 125, No. 5. - P. 115-161.

8. Borbolla F. A. Lessons to be learnt in managing the breech presentation at term: an 11-year single-centre retrospective study / F. A. Borbolla, A. Bagust, A. Bisits // Australian and New Zealand Journal of Obstetrics and Gynaecology. - 2014. Vol. 54, No. 4. - P. 333-339.

9. Никулин Л. А. Влияние различных способов родоразрешения при тазовом предлежании плода на течение периода ранней адаптации новорожденных и в ближайшем катамнезе / Л. А. Никулин, М. А. Литвинская, А. В. Поморцев // Кубанский научный медицинский вестник. - 2008. - № 3/4. - С. 120-125.

study of 10 years of experience. Journal of Perinatology, 35, 10, 803-808.

4. Podsvirova, Ye.V., Romanova, T.A., Gurova, M.M., Bonchuk, N.S., \& Tkacheva A.O. (2014). Vliyaniye techeniya beremennosti i rodov na sostoyaniye zdorovya novorozhdennogo rebenka [Influence of the course of pregnancy and childbirth on the state of health of a newborn child]. Nauchnyye vedomostiScientific Sheets, 24, 185, 81-84 [in Russian].

5. Davydova, Yu.V., Chibisova, I.V., Babich, T.Yu., \& Padalko, L.I. (2013). Tazovoye predlezhaniye: perinatalnyye aspekty [Breech position: perinatal aspects]. Zhinochyi likar - Woman's Doctor, 4, 27-30 [in Russian].

6. Cammu, H., Dony, N., Martens, G., \& Colman, R. (2014). Common determinants of breech presentation at birth in singletons: a population-based study. European Journal of Obstetrics \& Gynecology and Reproductive, 177, 106-109. 
7. Lyons, J., Pressey, T., Bartholomew, S., Liu, S., Liston, R.M., \& Joseph, K.S. (2015). Delivery of breech presentation at term gestation in Canada, 2003-2011. Obstetrics \& Gynecology, 125 5, 115-161.

8. Borbolla, F.A., Bagust, A., \& Bisits, A. (2014). Lessons to be learnt in managing the breech presentation at term: an 11-year single-centre retrospective study. Australian and New Zealand Journal of Obstetrics and Gynaecology, 54, 4, 333-339.
9. Nikulin, L.A., Litvinskaya, M.A., \& Pomortsev, A.V. (2008). Vliyaniye razlichnykh sposobov rodorazresheniya pri tazovom predlezhanii ploda na techeniye perioda ranney adaptatsii novorozhdennykh i v blizhayshem katamneze [Influence of different methods of delivery in pelvic presentation of the fetus during the period of early adaptation of newborns and in the nearest catamnesis]. Kubanskiy nauchnyy meditsinskiy vestnik -Kuban Scientific Medical Journal, 3, 4, 120-125 [in Russian]. 